\title{
Tribunal Superior do Trabalho
}

\section{PROCESSO TST-RR-277-59}

Interpelação da lei. - Prevalência do entendimiento que resulta de scu texto expresso sôbre a intenção do legislador. Efeito imlediato das leis de ordem pública.

Vistos e relatados êstes autos em que são partes, como Recorrente, Frigorifico Wilson do Brasil S. A. (Fazenda Wiison) e, como Recorridos, Antônio Centurion e outros:

A reclamação visou o recebimento de diferenças salariais além de $25 \%$ do mínimo legal, posteriormente à vigênciz: da Lei número 3.030 de 19 de dezembro de 19566 , que fixou naquela percentagem o máximo dos descontos sôbre alimentação nos casos em que a mesma lei estatui, e cuio mandamento não vinha sendo atendido pela reclamada. Contesttou esta a extensão do texto legal aos reclamantes, afirmando. se deinais, que ainda que assim não se entendesse, não caberia dar à lei efeito retroativo para alcançar ajustes anteriores. O Dr. Juiz de Direito de Rancharia julgou procedente $₫$ pedido, $c$, cin recurso ordinário, o Tribunal Regional do Trabalho da Segunda Região, em decisão unânime, confirmou tal julgado, nos têrmos seguintes:

"Não obstante o magnifica esfôrço do digno advogado à recorrente, no sencido de denonstrar, através dos traballhos legislativos que o objetivo da citada lei fôra tăo sòmente os estabelecimentos hoteleirơs su congêneres, não paira dúvida sua aplicação aos empregados em geral, como explicitamente se contém no seu artigo $2{ }^{\circ}$. "A disposição do artigo $1^{\circ}$ será aplicada aos trubalhadores em geral, desde que as refeições seianı preparadas e fornecidas no próprio estäbelecimento empregador". Em face dêsse dispositivo claro, nehuma dúvida poda pairar acêrca da incidência da Lei $\mathrm{n}^{\circ} 3.030$ à hipótese dos autos, uma vez que ficou fora de dúvida que, nä espécie, as refeições são preparadas e fornecidas $n_{0}$ próprio estabelecimento empregador. Portanto, a partir da vigência da Lei $\mathrm{n}^{2} 3.030$, não poderia a recorrente con- tinuar descontando $40 \%$ a titulo de alimentação a seus empregados remunerados à base da minimo regional. O ilustrado Juiz a quo. em seu brilhante pronunciamento, excluiu da decisão os empregados que não compareceram à audiência, bem como os que não outorgaram procuração, determinando a apuração do "quantum" na fase executória. Ademais com inegável acêrto, determinou que a decisão não aproveitará àqueles reclamantes que percebem salário supérior ao minimo regional, uma vez que a Lei $n^{\circ} 3.030$, como consta de seu artigo $1^{\circ}$ se acha integrada na estrutura do salário mínimo, em face da remissão explicita do artigo 82 da C.L.T.".

A revista foi interposta pela reclamada, com invocação a ambas as alineas do permissivo legal, apontando, como divergente aresto do Tribunal Regional da Terceira Região, (fls. 190 - lido) e como lei violada o próprio texto da Lei questionada de número 3.030 , de 1956 . Houve contra-razões, e a Procuradoria Geral assim opinou:

"Discute-se a aplicabilidade da Lei número 3.030 de 19-12-56, cuja incidência a recorrente contesta para os contratos celebrados anfes de sua vigência. Visou essa lei fixar um limite para o desconto a titulo de alimentação. Trata-se de norna de inediata aplicabilidade, destinada a reger tôdas as situações contratuais em que se revifique o referido desconto. A eficácia da lei atinge as condições presentes ou anteriores ajustando.as ao novo limite percentual. Ocorrido qualquer caso concreto, em que recrici o desconto alimentação, êsse terá de stibordinar-se ao teto legal, pelo alcance jurídico-sociai da nusma de caráter geral, aplicável conforme a regra do seu artigo $2^{\circ}$ " $\bar{c}^{\prime}$ disposição du artigo $1^{\circ}$ será aplicada aos trabalhadores em geral, desde que as refeições sejara preparadas e fornecidas no próprio estabelecimento empregador". Conhecido, mas imvrovido o apêlo, é o parecer.

Fio de Janeiro, 24 de abril de 1959. -(as.) Hilo Bastos, Procurador".

Fi' o relatório. 


\section{voTo}

A divergência se acha demonstrada, e por isso, conheço da revista, com apoio na alinea a do artigo 896 da Consolidação das Leis do Trabalho. Das teses em confronto, entretanto, entendo que é de prevalecer a que foi acolhida pelo Tribunzl da Segunda Região, tanto no que concerre à extensão da lei questionada aos recorridos, quer no tocante aos efeitos dessa lei no tempo. Ein verdade $\mathrm{e}$ em qué pese a intenção inicial do legislador, em limitar o alcance da lei a determinado grupo de trabalhndores, o certo é que seu texto final consequieste a cmendas recebidas, generalizou êsse alcancc, como resulta dos têrmos de seu aräigo $2^{\circ}$ verbis: "a disposição do artigo $1^{\circ}$ será aplicada aos trabalhadores em geral, deste que as refeições sejam preparadas e fornecidas no próprio estabelecimento empregador". Demais, não é de ser esquecida a lição do autorizado Ferrara, quando adverte que a lei deve interpretar-se por si mesma como incorporando um protimento e uma vontade própria, e ainda que o intérprete deve buscar, não aquilo que o legislador quis mas aquilo que na lei apartecer objetivamente querido e mens legis e não legislatori (vide Interpretação e aplicação da Lei, trad. pp. 41-42). Bem andaram, pois, as decisões recorridas, ao julgarem extensivas aos reclamantes os priceitos legais questionados, atentas as circunstâncias do caso. Por outro lado, não há como pretender limitar os efeitos da lei no t:mpo, dêles excluindo os postulantes, por serctn anteriores à lei seus contratos de trabalho. Inquestionável é o efeito imediato das leis de ordem pública, entre as quais se alinham as de proteção ao trabalho, observando-se, ademais, que a lei năo viria alcançar fatos passados, mas apenas os cfeitos futuros de atos anteriores ñ̃o consumados, de onde inexistir a pretendida retroatividade. Dai o meu voto, para negar provimento à revista.

\section{Istơ pôsto:}

Acordam os Juizes da Segunda Turmá do Tribunal Superior do Trabalho, sem divergência, conhecer do recurso e negar-lhe provimento.

Rio de Janeiro, 6 de julho de 1959. Oscar Saraiva, Presidente e Relator.

Ciente: João Antero dz Carualho, Prucurador Geral.
PROCESSO TST RR-1.249-59

Sendo as Iuntas de Conciliaçio e Julgamento órgãos colegiados, não se aplica a elas o principio de identidade fisica do Juiz.

Vistos e relatados êstes autos, em que são partes, como Embargante, Curıpanhia Fiação e Tecidos São Míguel e como Embargados, Rosa Maria da Conceição e cutros:

O v. acórdão embargado rejeitou entre as preliminares argüidas, a de falta de identidade fisica do Juiz instrutor e prolator da sentença da Junta. No mérito, deu provimento em parte, ao recurso da emirtèsa para determinar que o saldo de salário fôsse pago de forma simples e que o quantum da condenação fôsse apurado em execução (fôthas 180-183).

Dai os embargos. Renite a embargante na preliminar de nulidade da sentença, pela não observância do principio de identidade fisica. do Juiz instrutor e julgador. Ao propósito, indica acórdăo da Egrégia Terceira Turma (fls, 188). No mérito, ins'ste ma inexistència do despedimento dos reciamilos.

Admitidos os embargos (fls. 191), manifestou-se, afinal a Procurado:ia Geral pela rejeição dos embargos (fls. 191):

$\mathrm{E}^{\prime} \circ$ relatóric.

\section{vото}

Os embargos se ressentem de fundamentacão minima, sôbrz o merecimento da questão. Apenas, com referência à preliminar da identidade do Juiz, é que se iustificz o conhecimento dos embargos. Mas, em dêles conhecendo, rejeito-os, de vez que na Justiça do Trabalho o julgamento é fuizo nâo pelo Juiz, mas, pela Junta.

$\mathrm{E}^{\prime}$ certo que, no processo: funcionaram Juizes diferentes, mas, iss , năo impirta forcue, além de serem os vogais os mesmos, $\checkmark$ feito se acha suficientemence instruiclo. de sorte tal a permitir sem receio maior, o julgamento presidido por Juiz outro que não 0 instrutor da causa. No mais, a questão se resume no resxame de provas.

isto pôsto:

Acordam os Juizes do Tribuzal Superior ao Trabalho, por unanimidade de votos, cunhecer dos embargos, no mértto, por maioriat, reicitá-los:

Rio de Janeiro, 9 de se:enibr.s de 1959. -. Júlio Barata, Vice-Presidente, no exercicio evẹntual da Presidência. - Manuel Aìues Céldeira Neto. Relator.

Ciente: João Antero de Ca:valhc. Procurador Geral. 